\section{Claire Wood}

is marketing director, services, for the professional services firm Deloitte, where she has spent over 15 years specializing in providing marketing advice. She has extensive experience leading strategic marketing initiatives across multiple areas of Deloitte's business both in the United Kingdom and internationally. Her current responsibilities include Deloitte's four main service lines - audit, consulting, corporate finance and tax. With experience across the full marketing mix, she believes passionately in helping the marketers of today and tomorrow develop the skills they need to ensure that marketing remains a core driver of the business.

Keywords: B2B marketing, marketing automation, marketing transformation

\section{Harnessing the new opportunities}

\section{Risk of getting carried away}

\section{Marketing automation: Lessons learnt so far ...}

\author{
Claire Wood
}

Received (in revised form): 18th February 2015

\begin{abstract}
Marketing departments have been faced with an explosion in the number of technology solutions on offer to support their activities. This article offers practical lessons on what to consider before and during the adoption of marketing automation solutions.

Journal of Direct, Data and Digital Marketing Practice (2015) 16, 251-254. doi:10.1057/dddmp.2015.31
\end{abstract}

\section{The evolution of marketing technology}

Since the days of the single-sheet newspaper, marketers have always found creative ways to reach potential buyers for everything from snake charm oil to modern business services. The explosion of the internet and social media has provided us with a bewildering array of tools, approaches and channels from which to choose and operate. The evolution of marketing automation technology has the savvy marketer on the cusp of being able to harness these approaches to react at the speed of light to any scenario that can be imagined.

Although the history of marketing automation is relatively short, it was already valued at US $\$ 20$ bn worldwide in $2014^{1}$ as business-toconsumer and business-to-business (B2B) marketers begin to understand how to implement and improve marketing automation strategies. As is often the way with new technologies, there can be a tendency to get carried away on a wave of excitement, focusing on how much easier and simpler our lives would be, 'If only we had [insert here any one or all of the following]:

- a customer relationship management system (CRM);

- a sales/prospects tool;

- web analytics;

- a LinkedIn group;

- marketing automation; etc ...'.

This is, of course, by no means an exhaustive list. I am sure many of you reading this now, like myself, will bear the scars of introducing, integrating and implementing new technologies into your marketing toolkit. And so to my own lessons learnt so far vis-à-vis marketing automation.

\section{Lesson 1: Why?}

Be very clear as to both why you are considering marketing automation and why it is needed now. Last summer I heard a presentation given by 
Data never sleeps

Business research in video

\section{Rise of short-form video}

\section{Not for everybody}

\section{Articulating the benefits}

Carl Bates, the lead partner for Deloitte Analytics in the United Kingdom, that really brought this issue to life. He highlighted that the fastest-growing data set is the one that we ourselves are creating.

On average, at any given minute in 2014, we uploaded 72 hours of new video to YouTube, email users sent over 204 million messages and 277,000 tweets were posted to Twitter. ${ }^{2}$ Even if we had the time to dedicate to it, we are simply not equipped to process the proliferation of data and content now available to us.

So it is not a surprise that research by Google/Millward Brown Digital ${ }^{3}$ (coupled with Google's own internal data) highlighted mobile and video as the two fastest-growing channels to market. According to their research, 70 per cent of those surveyed watch video specifically to do research for business purposes. In addition, they identified a threefold growth in B2B mobile queries.

Mobile and video make accessing content quick, affordable, timely and controllable. Indeed, in our recent Mobile Consumer Survey, ${ }^{4}$ Deloitte predicts that the number of smartphones bought as upgrades is higher than for any other personal electrical device, with 24 per cent of UK adults planning to upgrade their smartphone this year. We predict that one billion smartphone upgrades will be purchased globally for the first time in 2015 .

In our Technology, Media \& Telecommunications Predictions ${ }^{5}$ for the UK in 2015 (http://www.deloitte.co.uk/tmtpredictions/), Deloitte also predicts that online short-form video (under $20 \mathrm{~min}$ ) should generate ten billion hours of viewing in 2015 - a spectacular achievement for a format that barely existed a decade ago. We predict that this year, global revenues from short, online video clips will generate over $£ 3$ bn, which is just over 1 per cent of global TV advertising and subscription revenues.

The answer to the question 'Why?' therefore becomes pretty straightforward for a marketer:

- to enable your clients to pull content from you to create their own experiences instead of trying to push it through against a tidal wave of content that is growing in volume and velocity every day;

- to enable them to get that content in the format that they want it in;

- and to enable them to get it when they want it.

\section{Lesson 2: What's in it for us?}

Why should your organization invest in marketing automation? Should everyone be jumping on the bandwagon? To quote my IDM B2B Marketing Council colleague Shane Redding, 'No'. ${ }^{6}$ However, if, like me, your organization is a large, complex B2B environment; is operating within a hugely competitive landscape where scores of other organizations are all competing with you for the time and attention of your target audience; and needs to nurture individual relationships to ensure the future growth of your business, then it is likely that you could derive benefit from a marketing automation system.

The key is to be able to articulate the main benefit that your organization wants to get from marketing automation — is it new lead 
Making friends with IT

\section{Behaviour and process changes}

\author{
If it's broken, it won't \\ fix it
}

generation or is it a deeper relationship with your current and potential clients? For me the benefits of marketing automation are that:

- it brings a high degree of efficiency and timeliness that simply cannot be matched by human intervention, no matter how responsive your marketing or client-facing teams are;

- it creates a personalized experience for each client driven by the client (and that, again, is something that simply could not be done by human intervention, particularly not on a volume basis);

- it increases our access to the user journey, which gives us the insight to tailor future client experiences according to actual client behaviour and demand;

- and it enables a swift response to that demand, or indeed to competitor threat.

\section{Lesson 3: What's in and what's out}

Be clear on the scope of marketing automation, bearing in mind that it enhances the effectiveness of CRM, but does not replace it. Many before have said it, but make the IT function and the chief information officer your new best friends. It should go without saying that a strong working relationship between marketing and IT will make life much easier, while presenting a united front to the rest of your organization is vital. This can also help manage the almost inevitable scope creep that seems to go handin-hand with projects of this nature.

\section{Lesson 4: Be realistic about your timescales}

This is not a quick fix. You need to understand any technology challenges that need to be overcome. You really need to think through the impact that this will have on your consumers or clients, and you need to consider any changes in behaviour or processes that will need to happen both inside your marketing function and beyond. We are 12 months into our marketing automation project and still have a way to go!

\section{Lesson 5: All change}

Automating bad processes doesn't magically make marketing better and, while this might appear like a 'no-brainer', it is astounding how often we look at automation to fix a broken process. It is essential that we engage marketing transformation prior to marketing automation. We must ensure that we understand and are prepared to implement and support the level of change that will be needed for this new way of working.

\section{Lesson 6: Engagement is key}

Ensure that the various senior stakeholders are aligned with the vision, and that they understand that marketing automation is a shift in thinking, not just a change in technology. Marketing automation is an amazing tool with 


\section{Return on relationship}

which to communicate with your audience and improve efficiencies, and it enables an organization to be client-centric, rather than product- and service-centric.

The irony is that the more hi-tech our world gets, the more our clients value a personal touch. Our clients don't want group spam - they want to be treated like individuals. So, my view is that the ultimate goal of any marketing automation programme has to be seen as what has been described as the 'Return on Relationship'. All the learning points above and the insights we have gained in the journey we are on pale into insignificance if we forget the fact that our clients - and indeed ourselves as consumers - are individuals. The tools of automation should lead us to strive to ensure that our interaction with them is as close to one-on-one as possible.

Ultimately, marketing automation should enable, rather than replace, human interaction with clients and customers. I truly hope that no marketing automation tool will ever replace the 'human touch'.

\section{References}

1. Worldwide Marketing Software Forecast. (2014-2020) IDC, http://www.idc.com/getdoc.jsp? containerId=251902, accessed 27 March 2015.

2. James, J. Domo, 'Data never sleeps', http://www.domo.com/blog/2014/04/data-never-sleeps-2-0/, accessed 23April 2014.

3. Statistics shared with the permission of Google.

4. Deloitte Mobile Consumer Survey. (2014) Survey conducted by Ipsos Mori May-July 2014. This particular survey finding first published in Deloitte Technology, Media \& Telecommunications Predictions 2015, www.deloitte.co.uk/tmtpredictions, accessed 12 January 2015.

5. Deloitte Technology, Media \& Telecommunications Predictions. (2015) www.deloitte.co.uk/ tmtpredictions, accessed 12 January 2015.

6. Redding, S. 'Marketing automation — debunking the hype', http://www.theidm.com/blog/ marketing-automation-debunking-the-hype/, accessed 13 June 2014. 